Jurnal Pembangunan Sosial 9 (Jun) 2006: 7-31

\title{
Graduates' Perception of the Value of Ethics Courses in University: A Case Study of UUM Alumni
}

\author{
MAHMOOD N. MOHAMED \\ SABITHA MARICAN
}

\begin{abstract}
ABSTRAK
Etika sering didefinisikan sebagai ilmu moral atau disiplin moral. Pengajian etika boleh menyediakan peraturan umum yang digunakan untuk mendefinisikan masalah serta menggunakan prinsip asasnya ke arah penyelesaian masalah berkaitan etika dan isu-isu moral. Dalam budaya Malaysia, etika didefinisikan sebagai pengetahuan dan pembelajaran yang diperolehi untuk tujuan kehidupan yang baik. Ia adalah konsep berkaitan dengan apa yang sepatutnya seseorang patut tahu atau buat. Selain pemerolehan pengetahuan, pendidikan universiti yang baik seharusnya juga berkaitan dengan pembinaan perilaku individu. Dalam konteks ini pengajian etika boleh menyediakan asas yang kukuh ke arah memperkembang dan memperbaiki perilaku individu. Kajian ini adalah berkaitan dengan pengalaman UUM dalam pengajaran kursus etika kepada pelajar sarjana muda. Tumpuan utama kajian ialah persepsi alumni UUM ke atas kursus-kursus etika yang telah diambil semasa mereka menjadi mahasiswa di UUM, serta persepsi mereka mengenai tahap kepentingan kursus tersebut kepada kedudukan dan pekerjaan mereka sekarang. Analisis dibuat berasaskan beberapa pembolehubah, seperti gender, etnik, pencapaian akademik, pekerjaan semasa serta gaji yang diperolehi. Hasil menunjukkan terdapat perkaitan di antara persepsi alumni mengenai kepentingan kursus etika ini berasaskan gender, etnik, lokasi geografi serta pencapaian akademik.
\end{abstract}

\begin{abstract}
Ethics is generally defined as the science of moral or moral discipline. The study of ethics can provide some general prescriptions that can be used to define problems and use its basic principles to solve problems pertaining to ethical and moral issues. In the Malaysian culture, ethics is defined as the learning and knowledge acquired for the sake of right living. It is a concept of what a person should know, be and do. Apart from the acquisition of knowledge, it is generally agreed that a wholesome university education should also address the issue of building the character of the individual. Specifically the study of ethics may provide a strong basis for the development and improvement of
\end{abstract}


The study of ethics can be traced back to the days of ancient Greece, and through time, philosophers have argued the subject matter from various standpoints. Issues pertaining to values and moral are also very synonymous to ethics and they are frequently discussed in the context of each other (Kerner, 1966; White, 1992).

Ethics is derived from the Greek word ethos, meaning character and moral is from the Greek word moralis meaning customs or manners. Ethics is a construct that is primarily used pertaining to the individual character of a person, whereas moral is the relationship between human beings. However, the construct of ethics and moral are often used interchangeably (White, 1992; Thiroux, 1995; Denise, Peterfreund \& White, 1999).

In philosophy, ethics is a specific area of study, which is the study on morality and for the most part, concentrates on the human conduct and values. In fact, ethics has also been defined as the science of moral or moral discipline. It is concerned with goodness and badness of character or disposition, or with the distinction between right and wrong. Therefore, we always refer to ethics or moral in the context of the person (an ethical worker) or to a specific act (lying is an immoral act) (Thiroux, 1995). In specific terms, when we talk about ethics, we usually mean normative ethics. The other is known as metaethics. The earlier concept refers to theories that are based on valid moral principles; these are actual moral statements (for example, abortion is wrong). The central feature of normative ethics is the moral principle (White, 1992, Mahoney, 1990). Principles are generally guidelines for the right conduct (for example, ethical conduct for psychologist). These principles in ethical theories are intentionally general so that they may apply to every situation we are likely to encounter (for example, do not unnecessary harm others). UUM believes that these basics must be taught at the tertiary level so that students can understand the underlying principles of good, moral and ethical behavior, as it can act as a foundation for their conduct.

Metaethics, on the other hand is the theoretical study centered on the analysis and meaning of the language used in ethical discourse and the logic used to justify ethical reasoning. Their concern is conceptual analysis and inquiry into the correct method for answering moral questions (White, 1992; Percesepe, 1995; Denise, Peterfreund \& White, 1999). This has been one application especially useful to social science students, who dwell in areas of reasoning and generalization (Cherrington, 1998). For the social scientist, the examination of moral behaviors entails the processes of definition, classification and generalization. We observe and compare mores, customs, traditions, morals and laws of different societies and formulate theories about the roles of morals in society; we study the relationships between moral and other variables such as criminality, deviance, equity and productivity, and therefore formulated that 
one's character. This study is related to the experience of UUM in the teaching of ethics to undergraduate students. It focuses on the perception of UUM alumni on the ethics courses that they studied while in UUM and the level of usefulness of these subjects to their current profession and standing. Analysis was performed across several variables such as gender, ethnic groups, academic performance, present occupation and salary. The results show some association in student perception towards the usefulness of these ethics courses taught in the university according to gender, ethnic, geographical location and some achievement variables.

\section{INTRODUCTION}

Usually, students in introduction to ethics class are confused between what is not ethical and what is wrong or illegal. They often provide some illegal conduct as examples of unethical behaviors (Mahmood, Sabitha \& Noran, 2001). This is also common among the general public (Mahmood \& Sabitha, 2001). Illegal conduct like stealing, sexual harassment and corruption lends no ethical justification, however, some individual conjecture reasons of such conduct within the realm of ethical relevance (Mahmood \& Sabitha, 1995). Thus the basis for teaching a course on ethics is to provide students with reasoning capacity in understanding ethical dilemma situation. This will facilitate them to come to a decision before hand if their actions are unethical or acceptable therefore taking the necessary steps to avoid it.

Ethics is an interesting field of study because it deals with the subjectivity of moral values, and it is always interpreted on a right-wrong dichotomy. We have seen successful government, business and corporate figures advocating the virtues of being ethical (Mahoney, 1990; Mahmood \& Sabitha, 2001). There are others who also argued that there are significant relationships between the presence of code of ethics or conduct and corporate violation (Matthews, 1988; White, 1992; Sabitha, 1999). Some even argued that writing a code of ethics is an important first step towards fewer violation of conduct (Percesepe, 1995; Denise, Peterfreund \& White, 1999; Sabitha, 2000). Basically, the argument touches on one's behavior, which must be in line with the accepted norms of a group or organization. To be ethical is to behave within the prescribed norms and culture. This can be acquired through vicarious or experiential learning. However, can ethics that are taught in classroom environment leave an impact on the individual's behavior later on in life? This is basically the purpose of this study, which intends to look at the experience of teaching of ethics in a university setting and if it has any effect on students later life when they enter the work place.

\section{MORALITY AND ETHICAL BEHAVIORS}


The general objective of the Introduction to Ethics course is to enable students to understand, internalize and demonstrate ethical behavior in their daily life and eventually at the work place. Specifically, at the end of the course, students should be able to achieve the following goals: define and describe the main concepts in ethics; demonstrate some ethical practices in their behavior; and abide by some guiding ethical principles in their daily and working life.

Looking at the objectives enumerated above, they comprise both the cognitive and the affective domains. The objective in the cognitive domain seems to focus mainly on the lower level of understanding. There is definitely a need to address the higher-level objectives. The second and third objectives are affective in nature.

The course comprises six sections, namely, (a) ethics as a branch of philosophy; (b) Islamic teaching and ethics; (c) ethics from the perspectives of Christianity, Hinduism and Buddhism; (d) Western secular ethics; (e) ethical values in Malaysian working life; and (f) ethical practices in the fields of business, management and administration. The rationale for focusing on the four religions as outlined in sections (b) and (c) is to address the four major religions of the Malaysian people. Twelve ethical work values that had been outlined and advocated by the Malaysian government are trustworthiness, cleanliness, dedication, discipline, responsibility, espirit de corp, justice, integration, knowledgeable, friendliness, accountability, and productivity were also addressed in the course.

Students were evaluated through two methods: (a) group assignment that comprises 50 percent of the total evaluation and, (b) a final examination, which carries another 50 percent of the total marks. Students were encouraged to have four members in each group and every group was required to write on any ethical issue they perceive to be important. Examples of group projects include topics on environment, globalization, healthy living and corruption. The duration of the final examination was two and a half hours, in which students were required to answer four essay questions. The first part of this written examination, which contributes a total of 40 percent, contains a compulsory question in which students were tested on their understanding of religious ethics. The second part of the examination was on Western ethics; the third on Malaysian work ethics and the fourth was on ethical practices in business, management and administration. For each of the second, third and fourth parts, students were given the choice to choose one of two given questions.

Since student enrolment for Introduction to Ethics was normally large - numbering to about 3,000 students, classes were broken into sizes of 150 students per class, easily making this course into twenty groups. Therefore, 
ethics and values are appropriate for the working of a contemporary productive society. It is on this basis and rationale that courses on ethics are offered to students at the tertiary level.

In our business culture, it is imperative to apply ethics because of several reasons, among others are the strong ties between religion and way of life, public sensitivity and customers' rights, increasing consumer safety, civil right movements and the public concern over issues like honesty, transparency and justice (Mahmood \& Sabitha, 2001; Oemar, Mahmood, Sabitha \& Dzahir, 2004). In fact, these concerns are not only directed to the business community but also more importantly, to the government sector. The public service must act and be seen as transparent, efficient, competent, and serve the public best interest (Sabitha \& Mahmood, 2005). In a nutshell, it is not so different from the concerns that were expressed in other parts of the world, like our western counterparts, and as stated by Mahoney (1990), all concerns about our environment, culture and way of life is towards preserving the world for our children. Therefore behaving in an ethical manner is the utmost consideration.

\section{TEACHING OF ETHICS AT UUM}

In general, the elements of ethical principles and reasoning are embedded in a plethora of business, management and other courses at UUM. However, departing from the arguments stated above on the importance of the philosophical and theoretical aspects of ethics, it has been deemed necessary that ethics is to be taught as a course to management students. In addition, apart from acquisition of knowledge, it is generally agreed that a complete university education should also address the issue of building the character of the individual. A course on ethics may provide the basis for the development of and improvement of one's character. At the end of that long educational journey, the individual is assumed to have acquired all the necessary knowledge, strength of judgment and moral virtues.

It is in line with this philosophy that Universiti Utara Malaysia, which was established on $15^{\text {th }}$ February 1984 , offers a university core course entitled "Introduction to Ethics". This course was initially a three-credit course but has been reduced to a two-credit course in the year 2000. In 1995, this course was taught at the School of Management targeted mainly for management and business students. However, it was then decided that all undergraduate students at this university need to take this course as part of their university's core curriculum. It was later changed to Introduction to Ethics which is taught by the School of Cognitive Science and Education (UUM Academic Calendar, 2000). At present all UUM students are required to take two 3-credits ethics courses: Business Ethics and Ethics and Cognitive Science. 
considerations. A plethora of Muslim, Christian, Hindu and contemporary modern day ethics and morality texts are used in the teaching of the subject matter (for example, Afzal Iqbal, 1992; Crooks, 1995; DeCallieres, 1994; Saral, 1999). This is basically a lecture-exam orientation course with a $20 \%$ group work, $20 \%$ individual submission, $20 \%$ midterm and the remaining $40 \%$ for the final exam.

UUM also offers ethics at graduate level, for example Ethics and Law for the M.Sc (Management) program. This paper is for students who want to increase their understanding and knowledge in the subject matter. This course introduces students to the concept of ethics and law, some theories in ethics, ethical practices in management, business and other areas that has some bearing on the law in practice, some general principles in law and the general relationship between ethical and legal practices. Amongst references used by this course is a mixture of Islamic ethical principles (Quassem, 1975), legal perspective (Bloom \& Fischer, 1988; Borrie, 1980) and contemporary ethics (Joshua, 1988). Assessment is done by case study (20\%), presentation of cases $(20 \%)$, tests $(30 \%)$ and final exam $(30 \%)$.

\section{TRACER STUDY}

After 17 years of its establishment, UUM has conducted two major tracer studies, and the data obtained for this paper is from the second study that surveyed graduates from 1995 to 1999 (Mohd Salleh, Mahmood, Mustafa, Zolkapli, Abdul Razak. S, Abdul Malek \& Abdul Razak, C., 2001). The total population of these cohorts is 11,322 .

Data were collected using several methods. One is by using mail questionnaires. A total of 9,770 questionnaires were sent out to known addresses of UUM graduates. Second is media (local newspapers) advertising, where graduates were asked to participate in the study by contacting our website; third is advertisement on the national web coordinator, Jaring and TMnet; and finally, a snowball technique was employed. Steps were taken to avoid double submission or counts of respondents. Extremities were also excluded from the analysis.

A total of 1,586 questionnaires were returned (14\%), out of which $41.3 \%$ were male and $58.7 \%$ were female (the current male: female student ratio is about 1:3); $72.1 \%$ were Malays, 23.3\% Chinese and 3.3\% Indians. Almost half of the respondents declared that they were brought up in a rural environment; the other half was from the urban area. More than half (54.2\%) put UUM as their first choice when registering for their tertiary education; $1.3 \%$ graduated with first class honors, $36.2 \%$ with second upper class degrees; and $62 \%$ with second 
the number of faculty members teaching this course was about twenty people. A coordinator is responsible for ensuring uniformity in teaching the course.

The teaching of the course was mainly through lectures. However, students were encouraged to participate in class discussion. An interview with the coordinator of the course revealed that there was a need to use case studies to promote discussion among students on the topics covered. The course also required students to read some magazines and identify ethical issues for discussion. Nine faculty members who were the initial group teaching the course had written a module on Introduction to Ethics, and used by students.

Before the Introduction to Ethics course was made compulsory since the 1997/1997 academic sessions, UUM students were required to take the Management Ethics course (since 1991/1992 session), a three credit compulsory course that employed the case study approach as the mode of teaching. Students who graduated earlier had taken this course instead of the introduction class. There are also other courses designed to address ethics within a certain field of study such as Ethics in the Helping Profession (SW3043), Ethics in Management \& Diplomacy (SG3523) and Ethics and Law (PN6013).

Students taking Bachelor of Social Work Management (BSWM) program are required to take a course entitled Ethics in the Helping Profession (SW3043). This course is specifically designed to introduce the basic concepts and applications of ethical principles in the social work profession. Specific focus is given to the understanding of ethical principles of the profession, which is outlined by the professional accreditation bodies such as the International Council of Social Work (ICSW) and the National Association of Social Work (NASW). This course is being conducted by using a seminar approach which can be divided in three parts; first, students will be provided with the basic understanding of ethical principles, professional considerations and guidelines; secondly, students will be grouped into a four to six person format and will go to the field to look for five ethical dilemma situations. The group will write all these cases. They will present and discuss two of the cases in class in the third phase of the course. A total of $60 \%$ is allocated for the seminar portion, of which $30 \%$ will be peer evaluated. Final examination carries a weightage of $40 \%$.

Another undergraduate program that offers a course in ethics is the Bachelor of International Affairs program entitled Ethics in Management \& Diplomacy (SG3523). This course provides students with a general and conceptual understanding of the philosophy, concepts and issues in ethics in modern life with specific emphasis in the field of diplomacy and international affairs. Inclusions of "high politics" (the independence and sovereignty of a state) "low politics" (the political, economic and social aspects of the state), diplomacy, ethics moral reasoning with specific reference to global and international 


$\begin{array}{lccccc} & 78.1 \% & 13.3 \% & 4.8 \% & 3.8 \% & \\ & 10.7 \% & 5.6 \% & 12.2 \% & 26.7 \% & \\ \text { No } & & & & & \\ & 682 & 237 & 36 & 11 & 966 \\ & 70.6 \% & 24.5 \% & 3.7 \% & 1.1 \% & \\ & 89.3 \% & 94.4 \% & 87.8 \% & 73.3 \% & \\ \text { Total } & 764 & 251 & 41 & 15 & 1071 \\ & & & & & \end{array}$

Table 3 looks at the association of the geographical locations where they were brought up, where $10.0 \%$ respondents who had more urban influence placed this course as important to their present career than those with rural influence $(9.9 \%)$ or respondent is from East Malaysia $(8.7 \%)$, but the association is not significant.

Table 3

Introduction to Ethics is among the Top Five Courses which is useful for My Present Career according to of Geographical Location

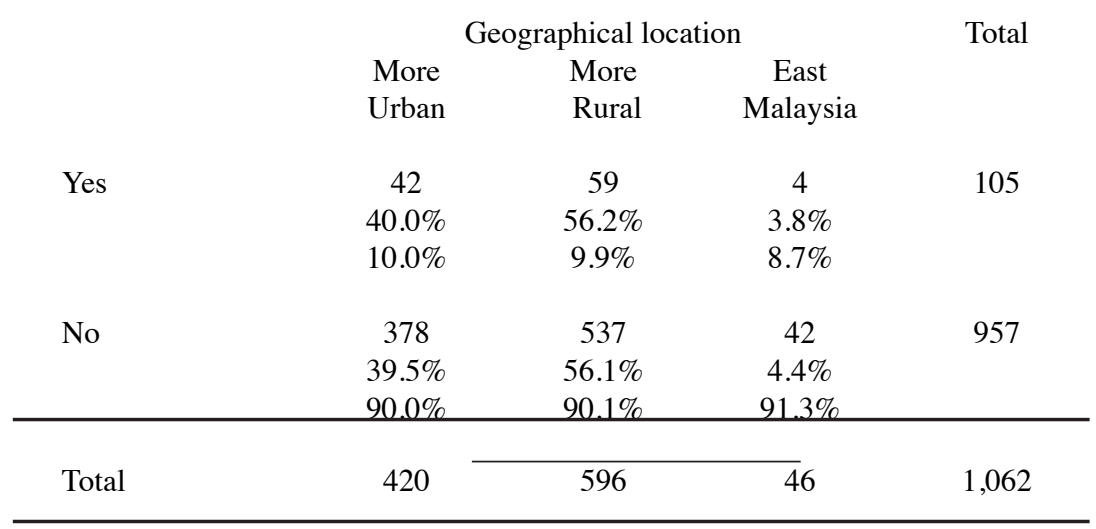

$\chi^{2}(2)=0.079, p>0.05$

Table 4 shows that more of the second lower class degree students rated this course in the top five list compared to the upper second or first class group. Similarly, those scoring lower in their CGPAs (2.00-2.49) ranked this course as more important to their career (Table 5). Those who have been employed but currently not holding any job, and those who are employed but presently studying, both tend to agree more as to the importance of this course to their 
lower class degrees. At present, 92.1\% are employed and 58.8\% are married.

\section{INTRODUCTION TO ETHICS COURSE}

One of the items in the questionnaire, asked respondents to rate the top five courses that they considered as useful to them in their present career A total of $105(9.8 \%)$ students rated the course Introduction to Ethics as one of the top five as opposed to $966(90.2 \%)$ who did not rate this course as one the top five. This is used to investigate students' perception on the value of ethics course and the background of those perceiving ethics as an important subject.

Tables 1 to 6 show the distribution of those respondents who listed Introduction to Ethics as the top five courses important to their career in relations to their gender, ethnic group, the influence of the geographical location where they were brought up, the class of degree received their academic performance and their present occupational status.

Table 1 indicates that there are more female respondents (10.3\%) who ranked this course as one of the top 5 compared to their male counterparts (however it was not significant). Table 2 shows that more respondents from "other races" category $(26.7 \%)$ ranked this course as important followed by Indians $(12.2 \%)$, Malays $(10.7 \%)$ and Chinese $(5.6 \%)\left(\chi^{2}(3)=10.904, p<.05\right)$.

Table 1

Introduction to Ethics is among the Top Five Courses which is useful for My Present Career according to Gender

\begin{tabular}{cccc} 
& \multicolumn{2}{c}{ Gender } & Total \\
& Male & Female & \\
\hline \multirow{2}{*}{ Yes } & 38 & 67 & 105 \\
& $36.2 \%$ & $63.8 \%$ & \\
& $9.0 \%$ & $10.3 \%$ & \\
\hline No & 385 & 581 & \multirow{2}{*}{966} \\
& $39.9 \%$ & $60.1 \%$ & \\
\hline Total & $91.0 \%$ & $89.7 \%$ & 1071
\end{tabular}

$\chi^{2}(1)=0.532, p>0.05$

Tahle 2

Introduction to Ethics is among the Top Five Courses which is useful for My Present Career according to Ethnic Group

$\begin{array}{cccc}\text { Ethnic group } & & \text { Total } \\ \text { Malay Chinese } & \text { Indian Others }\end{array}$

Yes

82

14

5

4

105 


\begin{tabular}{|c|c|c|c|c|c|c|}
\hline & & & $\begin{array}{c}\text { still } \\
\text { studying }\end{array}$ & studying & $\begin{array}{c}\text { working } \\
\text { before }\end{array}$ & \\
\hline \multirow[t]{3}{*}{ Yes } & 90 & 0 & 7 & 0 & 8 & 105 \\
\hline & $85.7 \%$ & & $6.7 \%$ & & $7.6 \%$ & \\
\hline & $9.4 \%$ & & $16.3 \%$ & & $16.3 \%$ & \\
\hline \multirow[t]{3}{*}{ No } & 868 & 2 & 36 & 19 & 41 & 966 \\
\hline & $89.9 \%$ & $0.2 \%$ & $3.7 \%$ & $2.0 \%$ & $4.2 \%$ & \\
\hline & $90.6 \%$ & $100.0 \%$ & $83.7 \%$ & $100.0 \%$ & $83.7 \%$ & \\
\hline Total & 985 & 2 & 43 & 19 & 49 & 1,071 \\
\hline
\end{tabular}

Table 7

Introduction to Ethics is among the Top Five Courses which is useful for My Present Career according to Present Employment Sector

\begin{tabular}{cccc}
\multicolumn{3}{c}{ Employment sector } & Total \\
\hline Government & Statutory & Private & Own \\
Service & Body & Business
\end{tabular}

\begin{tabular}{cccccc} 
Yes & 20 & 6 & 76 & 0 & 102 \\
\hline \multirow{3}{*}{ No } & $19.6 \%$ & $5.9 \%$ & $74.5 \%$ & & \\
& $10.2 \%$ & $19.4 \%$ & $9.7 \%$ & & \\
& 177 & 25 & 711 & 2 & 915 \\
& $19.3 \%$ & $2.7 \%$ & $77.7 \%$ & $0.2 \%$ & \\
& $89.8 \%$ & $80.6 \%$ & $90.3 \%$ & $100.0 \%$ & \\
\hline Total & 197 & 31 & 787 & 2 & 1,017
\end{tabular}

$\chi^{2}(3)=3.335, p>0.05$

Table 8

Introduction to Ethics is among the Top Five Courses which is useful for My Present Career according to Income Group

\begin{tabular}{cccccc}
\hline & \multicolumn{2}{c}{ Income group } & & Fotal \\
& Less & RM1,000- & RM1,501- & More than & \\
RM1,000.00 & RM1,500 & RM2,000 & RM2,000 & \\
Yes & 22 & 28 & 25 & 23 & 98
\end{tabular}


present career (Table 6). Similarly, those who are employed in the statutory body and public service have the tendency to rank the course as more important (Table 7). Quite interesting too, these are among the lower and mid high-income bracket group However these relationships do not occur at a significant level (Table 8)

Table 4

Introduction to Ethics is among the Top Five Courses which is useful for My Present Career according to Class of Degree Received

\begin{tabular}{ccccc} 
& \multicolumn{3}{c}{ Class of degree received } & Total \\
\hline \multirow{2}{*}{ Yes } & First Class & $\begin{array}{c}\text { Second Class } \\
\text { Upper }\end{array}$ & $\begin{array}{c}\text { Second Class } \\
\text { Lower }\end{array}$ & \\
& & 373 & 68 & 105 \\
\hline \multirow{2}{*}{ No } & & $5.2 \%$ & $64.8 \%$ & \\
& 16 & $9.8 \%$ & $10.1 \%$ & \\
& $1.7 \%$ & 340 & 608 & \\
\hline \multirow{2}{*}{ Total } & $100.0 \%$ & $35.3 \%$ & $63.1 \%$ & 1,069 \\
\hline
\end{tabular}

$\chi^{2}(2)=1.786, p>0.05$

Table 5

Introduction to Ethics is among the Top Five Courses which is useful for My Present Career according to Academic Performance

\begin{tabular}{|c|c|c|c|c|c|}
\hline & \multicolumn{4}{|c|}{ Academic performance } & \multirow[t]{2}{*}{ Total } \\
\hline & $2.0-2.49$ & $2.5-2.99$ & $3.0-3.49$ & $3.5-4.0$ & \\
\hline \multirow[t]{3}{*}{ Yes } & 19 & 46 & 31 & 5 & \multirow[t]{3}{*}{101} \\
\hline & $18.8 \%$ & $45.5 \%$ & $30.7 \%$ & $5.0 \%$ & \\
\hline & $15.1 \%$ & $8.9 \%$ & $10.9 \%$ & $5.4 \%$ & \\
\hline \multirow[t]{3}{*}{ No } & 107 & 472 & 253 & 87 & \multirow[t]{3}{*}{919} \\
\hline & $11.6 \%$ & $51.4 \%$ & $27.5 \%$ & $9.5 \%$ & \\
\hline & $84.9 \%$ & $91.1 \%$ & $89.1 \%$ & $94.6 \%$ & \\
\hline Total & 126 & 518 & 284 & 92 & 1,020 \\
\hline
\end{tabular}

$\chi^{2}(3)=6.777, p>0.05$

Table 6

Introduction to Ethics is among the Top Five Courses which is useful for My Present Career according Present Occupational Status

\begin{tabular}{|c|c|c|c|}
\hline \multicolumn{4}{|c|}{ Present occupational status } \\
\hline Yes & $\begin{array}{ll}\text { No } & \text { Have a } \\
& \text { job but }\end{array}$ & $\begin{array}{l}\text { No job } \\
\text { but still }\end{array}$ & $\begin{array}{c}\text { No job } \\
\text { but have been }\end{array}$ \\
\hline
\end{tabular}


$\left(\chi^{2}(3)=20.148, p<.05\right)$ (Table 15$)$, but with slightly higher income bracket, though not significant (Table 16). Therefore, the profile of graduates who were in agreement that the Management Ethics course is one of the top 5 courses useful for their current occupation is a male graduate, a non-Indian and non-Chinese ethnic background, those who are both high and low (extremes) academic achievers and performers, serving the public sector, with a moderate income.

\section{Table 9}

Management Ethics is among the Top Five Courses which is useful for My Present Career according to Gender

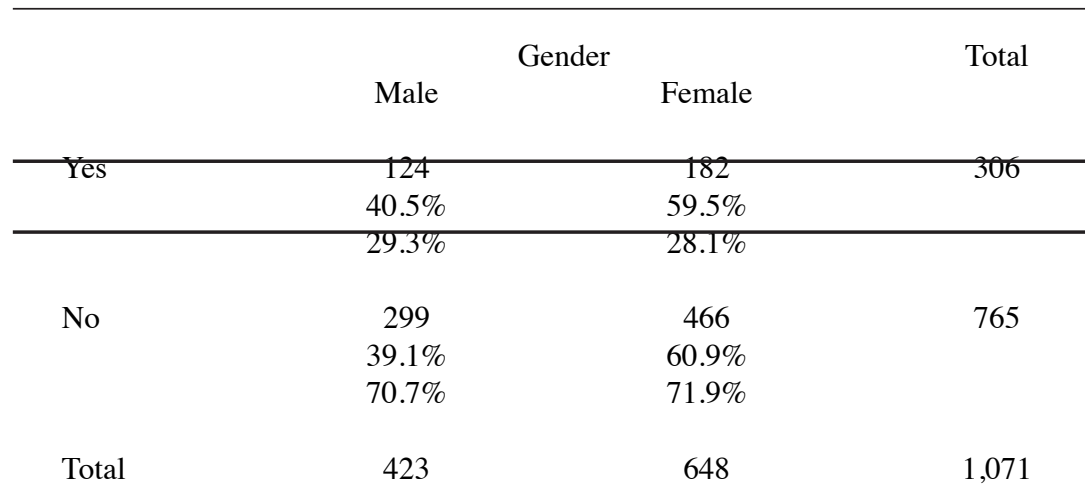

$\chi^{2}(1)=0.189, p>0.05$

Table 10

Management Ethics is among the Top Five Courses which is useful for My Present Career according to Ethnic Group

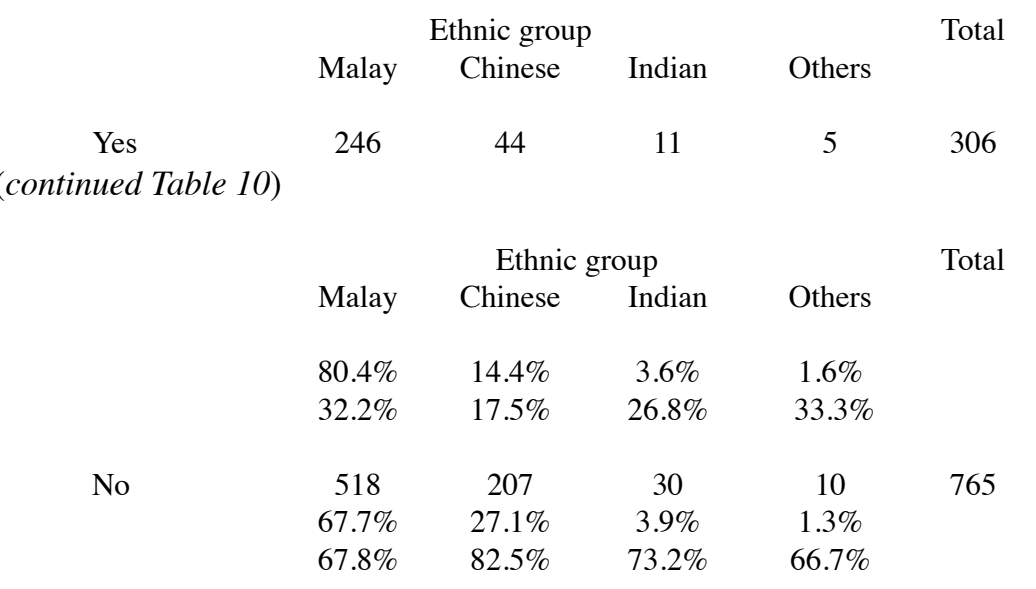




\begin{tabular}{|c|c|c|c|c|c|}
\hline & $22.4 \%$ & $28.6 \%$ & $25.5 \%$ & $23.5 \%$ & \\
\hline & $12.1 \%$ & $9.6 \%$ & $8.7 \%$ & $10.2 \%$ & \\
\hline No & $\begin{array}{c}160 \\
18.0 \% \\
87.9 \%\end{array}$ & $\begin{array}{c}263 \\
29.6 \% \\
90.4 \%\end{array}$ & $\begin{array}{c}264 \\
29.7 \% \\
91.3 \%\end{array}$ & $\begin{array}{c}203 \\
22.8 \% \\
89.8 \%\end{array}$ & 890 \\
\hline Total & 182 & 291 & 289 & 226 & 988 \\
\hline
\end{tabular}

Therefore, the profile of graduates who rated the Introduction to Ethics course as important to their present career are female, Indians and other minority ethnic group, those who were brought up in the urban environment, those graduated with $2^{\text {nd }}$ lower degrees, and serve in government agencies, with lower to mid income bracket. However, apart from ethnic variable, others have no significant relationship and therefore must be interpreted in context.

\section{MANAGEMENT ETHICS COURSE}

As mentioned in the earlier part of this paper, prior to the Introduction to Ethics course, all UUM students were required to take the Management Ethics course,

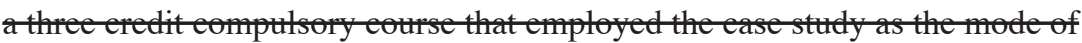
teaching. Students graduated since 1995 had taken this course instead of the introduction class.

A total of 306 respondents (28.6\%) said they ranked this course as one of the top five courses that are useful to their present career. Table 9 presents differences between genders, where slightly more male respondents $(29.3 \%)$ agreed to the usefulness of this course to their present career than the female respondents $(28.1 \%)$. When compared with their ethnic group, more of those from other races ranked the course higher $(33.3 \%)\left(\chi^{2}(3)=20.148, p<05\right)$, followed by the Malays (32.2\%), Indians (26.8\%) and the Chinese graduates $(17.5 \%)$ (Table $10)$. Interestingly the influence of geographical location yielded significant association, where those graduates who were brought up in East Malaysia (Table 11) ranked this course as more important $(43.5 \%)$, followed by those brought up in the rural environment $(29.5 \%)$ and the urban $(25.5 \%)$ influences (Table 11) $\left(\chi^{2}(2)=7.254, p<.05\right)$. Table 12 shows that more of those from the $2^{\text {nd }}$ lower class degree ranked this course as one of the top 5 (32.2\%) followed by the $1^{\text {th }}$ class group $(31.3 \%)$ and the $2^{\text {nd }}$ upper group $(21.8 \%)\left(\chi^{2}(2)=13.139 . \mathrm{p}<.05\right)$. This is also true for those with lower academic performance $\left(\chi^{2}(3)=22.213\right.$. $\mathrm{p}<.05$ ) as oppose to those with higher CGPAs (Table 12 and 13); and graduates with jobs (30.4\%) (Tabte 14), who served int the govermment sector (33.0\%) 


\begin{tabular}{|c|c|c|c|c|c|}
\hline \multicolumn{6}{|c|}{ Table 13} \\
\hline \multicolumn{6}{|c|}{$\begin{array}{l}\text { Management Ethics is among the Top Five Courses which is } \\
\text { useful for My Present Career according to Academic Performance }\end{array}$} \\
\hline & \multicolumn{3}{|c|}{ Academic performance } & & \multirow[t]{2}{*}{ Total } \\
\hline & $2.0-2.49$ & $2.5-2.99$ & $3.0-3.49$ & $3.5-4.0$ & \\
\hline \multirow[t]{3}{*}{ Yes } & 51 & 154 & 70 & 12 & 287 \\
\hline & $17.8 \%$ & $53.7 \%$ & $24.4 \%$ & $4.2 \%$ & \\
\hline & $40.5 \%$ & $29.7 \%$ & $24.6 \%$ & $13.0 \%$ & \\
\hline \multirow[t]{3}{*}{ No } & 75 & 364 & 214 & 80 & 733 \\
\hline & $10.2 \%$ & $49.7 \%$ & $29.2 \%$ & $10.9 \%$ & \\
\hline & $59.5 \%$ & $70.3 \%$ & $75.4 \%$ & $87.0 \%$ & \\
\hline Total & 126 & 518 & 284 & 92 & 1,020 \\
\hline
\end{tabular}

$\chi^{2}(3)=22.213, \mathrm{p}<0.05$

\section{Table 14}

Management Ethics is among the Top Five Courses which is useful for My Present Career according to Present Occupation

\begin{tabular}{|c|c|c|c|c|c|c|}
\hline & \multicolumn{5}{|c|}{ Present occupation } & \multirow[t]{2}{*}{ Total } \\
\hline & Yes & No & $\begin{array}{c}\text { Have a job } \\
\text { but still } \\
\text { studying }\end{array}$ & $\begin{array}{l}\text { No job } \\
\text { but still } \\
\text { stmdying }\end{array}$ & $\begin{array}{l}\text { No job but } \\
\text { have been } \\
\text { working }\end{array}$ & \\
\hline & & & & & before & \\
\hline Yes & $\begin{array}{c}291 \\
95.1 \% \\
30.4 \%\end{array}$ & 0 & $\begin{array}{c}11 \\
3.6 \% \\
25.6 \%\end{array}$ & 0 & $\begin{array}{c}4 \\
1.3 \% \\
8.2 \%\end{array}$ & 306 \\
\hline
\end{tabular}

(continued Table 14)

\begin{tabular}{|c|c|c|c|c|c|c|}
\hline & \multicolumn{5}{|c|}{ Present occupation } & Total \\
\hline & Yes & No & Have a job & No job & No job but & \\
\hline & & & $\begin{array}{l}\text { but still } \\
\text { studying }\end{array}$ & $\begin{array}{l}\text { but still } \\
\text { studying }\end{array}$ & $\begin{array}{c}\text { have been } \\
\text { working } \\
\text { before }\end{array}$ & \\
\hline \multirow[t]{2}{*}{ No } & 667 & 2 & 32 & 19 & 45 & 765 \\
\hline & $87.2 \%$ & $0.3 \%$ & $4.2 \%$ & $2.5 \%$ & $5.9 \%$ & \\
\hline
\end{tabular}




\begin{tabular}{llllll} 
Total & 764 & 251 & 41 & 15 & 1,071 \\
\hline
\end{tabular}

$\chi^{2}(3)=20.148, \mathrm{p}<0.05$

Tabie 11

Management Ethics is among the Top Five Courses which is useful for My Present Career according to of Geographical Location

\begin{tabular}{|c|c|c|c|c|}
\hline & \multicolumn{3}{|c|}{ Geographical location } & \multirow[t]{2}{*}{ Tota } \\
\hline & More Urban & More Rural & East Malaysia & \\
\hline \multirow[t]{3}{*}{ Yes } & 107 & 176 & 20 & 303 \\
\hline & $35.3 \%$ & $58.1 \%$ & $6.6 \%$ & \\
\hline & $25.5 \%$ & $29.5 \%$ & $43.5 \%$ & \\
\hline \multirow[t]{3}{*}{ No } & 313 & 420 & 26 & 759 \\
\hline & $41.2 \%$ & $55.3 \%$ & $3.4 \%$ & \\
\hline & $74.5 \%$ & $70.5 \%$ & $56.5 \%$ & \\
\hline
\end{tabular}

$\chi^{2}(2)=7.254, \mathrm{p}<0.05$

Table 12

Management Ethics among the Top Five Courses which is useful for My Present Career according to Class of Degree Received

\begin{tabular}{|c|c|c|c|c|}
\hline & \multicolumn{3}{|c|}{ Class of degree received } & Total \\
\hline \multirow{5}{*}{ Yes } & First Class & $\begin{array}{l}\text { Second Class } \\
\text { Upper }\end{array}$ & $\begin{array}{l}\text { Second Class } \\
\text { Lower }\end{array}$ & \multirow[b]{2}{*}{305} \\
\hline & $\begin{array}{c}5 \\
1.6 \% \\
31.3 \%\end{array}$ & $\begin{array}{c}82 \\
26.9 \% \\
21.8 \%\end{array}$ & $\begin{array}{c}218 \\
71.5 \% \\
32.2 \%\end{array}$ & \\
\hline & 2) & & & \\
\hline & \multicolumn{3}{|c|}{ Class of degree received } & \multirow[t]{2}{*}{ Total } \\
\hline & First Class & $\begin{array}{l}\text { Second Class } \\
\text { Upper }\end{array}$ & $\begin{array}{l}\text { Second Class } \\
\text { Lower }\end{array}$ & \\
\hline \multirow[t]{3}{*}{ No } & 11 & 295 & 458 & \multirow[t]{3}{*}{764} \\
\hline & $1.4 \%$ & $38.6 \%$ & $59.9 \%$ & \\
\hline & $68.8 \%$ & $78.2 \%$ & $67.8 \%$ & \\
\hline
\end{tabular}




\section{OTHER ETHICS COURSES}

Respondents are also asked as how they perceived the usefulness of three other ethics courses, namely Ethics and Law (PN6013). Ethics in Management \& Diplomacy (SG3523) and Ethics in the Helping Profession (SW3043). Only $10.6 \%$ (117) agreed that ethics is more important than other courses. Table 17 shows that equal percentage of male and female respondents agree that ethics courses are necessary. When compared amongst ethnic group, more of the Matays agreed that these courses are important (12.6\%) followed by the fndtians, other races, and the Chinese $\left(\chi^{2}(3)=12.587, \mathrm{p}<.05\right)$ (Table 18). Respondents who were brought up in a rurat enviromment stated that courses in ethres are more important $(12.9 \%)$ compared to the East Malaysian $(8.5 \%)$ and the urbaninfluenced group $(7.5 \%)\left(\chi^{2}(2)=8.067, \mathrm{p}<.05\right)$ (Table 19).

Table 17

The Necessity of Ethics Courses Compared to other Courses according to Gender

\begin{tabular}{|c|c|c|c|}
\hline & \multicolumn{2}{|c|}{ Gender } & \multirow[t]{2}{*}{ Total } \\
\hline & Male & Female & \\
\hline \multirow[t]{3}{*}{ Yes } & -45 & 72 & 117 \\
\hline & $38.5 \%$ & $61.5 \%$ & \\
\hline & $10.3 \%$ & $10.8 \%$ & \\
\hline \multirow[t]{3}{*}{ No } & 390 & 593 & 983 \\
\hline & $39.7 \%$ & $60.3 \%$ & \\
\hline & $89.7 \%$ & $89.2 \%$ & \\
\hline Total & 435 & 665 & 1,100 \\
\hline
\end{tabular}

Table 18

The Necessity of Ethics Courses Compared to other Courses according to Ethnic Group

\begin{tabular}{cccccc} 
& \multicolumn{2}{c}{$\begin{array}{c}\text { Ethnic group } \\
\text { Chinese }\end{array}$} & $\begin{array}{c}\text { Indian } \\
\text { Malay }\end{array}$ & $\begin{array}{c}\text { Others } \\
\text { Yes }\end{array}$ & \multicolumn{5}{c}{ Total } \\
\cline { 2 - 5 } & 100 & 12 & 4 & 1 & \multirow{2}{*}{117} \\
& $85.5 \%$ & $10.3 \%$ & $3.4 \%$ & $0.9 \%$ & \\
\hline & $12.6 \%$ & $4.8 \%$ & $9.8 \%$ & $6.7 \%$ & \\
\hline
\end{tabular}




\begin{tabular}{lllllll} 
Total & 958 & 2 & 43 & 19 & 49 & 1,071 \\
\hline
\end{tabular}

$\chi^{2}(4)=20.117, \mathrm{p}<0.05$

Table 15

Management Ethics is among the Top Five Courses which is useful for My Present Career according to Present Employment Sector

\begin{tabular}{cccccc}
\multicolumn{5}{c}{ Employment sector } & \multirow{2}{*}{ Total } \\
\hline & Service & Body & & Business & \\
\hline \multirow{2}{*}{ Yes } & 65 & 8 & 227 & 0 & 300 \\
& $21.7 \%$ & $2.7 \%$ & $75.7 \%$ & & \\
& $33.0 \%$ & $25.8 \%$ & $28.8 \%$ & & \\
No & 132 & 23 & 560 & 2 & 717 \\
& $18.4 \%$ & $3.2 \%$ & $78.1 \%$ & $0.3 \%$ & \\
& $67.0 \%$ & $74.2 \%$ & $71.2 \%$ & $100.0 \%$ & \\
Total & 197 & 31 & 787 & 2 & 1,017
\end{tabular}

$\chi^{2}(3)=20.148, \mathrm{p}<0.05$

Table 16

Management Ethics is among the Top Five Courses which is useful for My Present Career according to Income Group

\begin{tabular}{|c|c|c|c|c|c|}
\hline & \multicolumn{4}{|c|}{ Income group } & \multirow[t]{2}{*}{ Total } \\
\hline & $\begin{array}{c}\text { Less } \\
\text { RM1,000.00 }\end{array}$ & $\begin{array}{l}\text { RM1,000- } \\
\text { RM1,500 }\end{array}$ & $\begin{array}{c}\text { RM1,501- } \\
\text { RM2,00 }\end{array}$ & $\begin{array}{r}\text { More than } \\
\text { RM2,000 }\end{array}$ & \\
\hline \multirow[t]{3}{*}{$\begin{array}{c}\text { Yes } \\
\text { (continued T }\end{array}$} & $1010^{52}$ & 75 & 92 & 70 & 289 \\
\hline & $\begin{array}{c}\text { Less } \\
\text { RM1,000.00 }\end{array}$ & $\begin{array}{c}\text { Income group } \\
\text { RM1,000- } \\
\text { RM1,500 }\end{array}$ & $\begin{array}{r}\text { RM1,501- } \\
\text { RM2,00 }\end{array}$ & $\begin{array}{l}\text { More than } \\
\text { RM2,000 }\end{array}$ & Total \\
\hline & $\begin{array}{l}18.0 \% \\
28.6 \%\end{array}$ & $\begin{array}{l}26.0 \% \\
25.8 \%\end{array}$ & $\begin{array}{l}31.8 \% \\
31.8 \%\end{array}$ & $\begin{array}{l}24.2 \% \\
31.0 \%\end{array}$ & \\
\hline \multirow[t]{2}{*}{ No } & $\begin{array}{r}130 \\
18.6 \%\end{array}$ & $\begin{array}{r}216 \\
30.9 \%\end{array}$ & $\begin{array}{c}197 \\
28.2 \% \\
\end{array}$ & $\begin{array}{c}156 \\
22.3 \% \\
\end{array}$ & 699 \\
\hline & $71.4 \%$ & $74.2 \%$ & $68.2 \%$ & $69.0 \%$ & \\
\hline Total & 182 & 291 & 289 & 226 & 988 \\
\hline
\end{tabular}




\begin{tabular}{ccccc}
\hline Yes & 0 & 29 & 88 & 117 \\
& & $24.8 \%$ & $75.2 \%$ & \\
\cline { 2 - 4 } No & 17 & $3.7 \%$ & $12.5 \%$ & \\
& $1.7 \%$ & $35.7 \%$ & $62.6 \%$ & \\
& $100.0 \%$ & $92.3 \%$ & $87.5 \%$ & \\
Total & 17 & 379 & 702 & 1,098 \\
$\chi^{2}(2)=8.226, p<0.05$ & & & & \\
\hline
\end{tabular}

Table 21

The Necessity of Ethics Courses Compared to other Courses according to Academic Performance

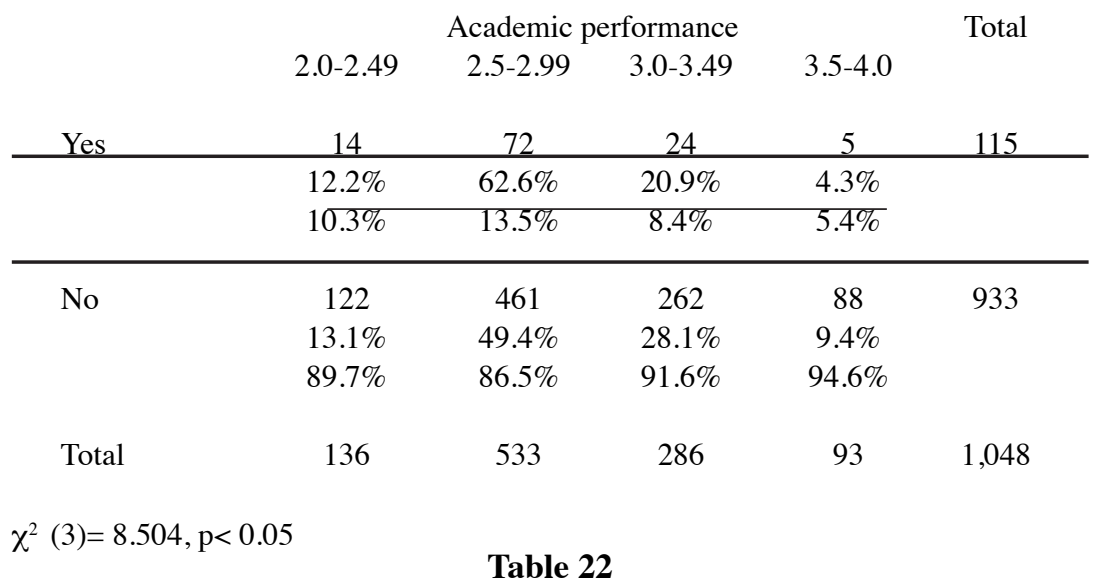

The Neeessity of Ethies Courses Compared to other Courses aecording to Present Occupation

\begin{tabular}{|c|c|c|c|c|c|c|}
\hline \multicolumn{6}{|c|}{ Present occupation } & \multirow{2}{*}{ Total } \\
\hline & Yes & No & $\begin{array}{c}\text { Have a job } \\
\text { but still } \\
\text { studying }\end{array}$ & $\begin{array}{l}\text { No job } \\
\text { but still } \\
\text { studying }\end{array}$ & $\begin{array}{c}\text { No job but } \\
\text { have been } \\
\text { working before }\end{array}$ & \\
\hline \multirow[t]{3}{*}{ Yes } & 98 & 3 & 8 & 4 & 4 & \multirow{3}{*}{117} \\
\hline & $83.8 \%$ & $2.6 \%$ & $6.8 \%$ & $3.4 \%$ & $3.4 \%$ & \\
\hline & $10.2 \%$ & $9.7 \%$ & $18.6 \%$ & $21.1 \%$ & $8.2 \%$ & \\
\hline \multirow[t]{2}{*}{ No } & 860 & 28 & 35 & 15 & 45 & \multirow[t]{2}{*}{983} \\
\hline & $87.5 \%$ & $2.8 \%$ & $3.6 \%$ & $1.5 \%$ & $4.6 \%$ & \\
\hline
\end{tabular}




$\begin{array}{lccccc}\text { No } & 693 & 239 & 37 & 14 & 983 \\ & 70.5 \% & 24.3 \% & 3.8 \% & 1.4 \% & \\ & 87.4 \% & 95.2 \% & 90.2 \% & 93.3 \% & \\ \text { Total } & & & & & \\ & 793 & 251 & 41 & 15 & 1,100\end{array}$

$\chi^{2}(3)=12.587, \mathrm{p}<0.05$

Table 19

The Necessity of Ethics Courses Compared to other Courses according to Geographieal Loeation

\begin{tabular}{|c|c|c|c|c|}
\hline & \multicolumn{3}{|c|}{ Geographical location } & \multirow[t]{2}{*}{ Total } \\
\hline & More Urban & More Rural & East Malaysia & \\
\hline \multirow[t]{3}{*}{ Yes } & 32 & 80 & 4 & 116 \\
\hline & $27.6 \%$ & $60.9 \%$ & $3.4 \%$ & \\
\hline & $7.5 \%$ & $12.9 \%$ & $8.5 \%$ & \\
\hline \multirow[t]{3}{*}{ No } & 394 & 538 & 43 & 975 \\
\hline & $40.4 \%$ & $55.2 \%$ & $4.4 \%$ & \\
\hline & $92.5 \%$ & $87.1 \%$ & $91.5 \%$ & \\
\hline Total & 426 & 618 & 47 & 1,091 \\
\hline
\end{tabular}

$\chi^{2}(2)=8.067, \mathrm{p}<0.05$

Likewise, perception of the usefulness of the ethics courses seem to be associated with academic achievement $\left(\chi^{2}(2)=8.226, \mathrm{p}<.05\right)($ Table 20). When the Chi-Square amalysis was carried out according to CGPA, it was found that more of students from the lower CGPA (2.00-2.49) perceived the ethics courses to be important $\left(\chi^{2}(3)=8.504, p<.05\right)$ (Table 21). In terms of occupational status. more of those who do not have a job but still studying agreed to the importance of these ethics courses $(21.1 \%)$ as compared to other groups, although not significant (Table 22). Those who are working in statutory bodies also state higher percentage of agreement $(16.1 \%)$ when compared to respondents working in the civil service $(13.7 \%)$ or those employed in the private sector $(9.5 \%)$, but this trend is also not at a significant level (Table 23).

Table 20

The Necessity of Ethics Courses Compared to other Courses according to Class of Degree Received 


\begin{tabular}{cccccc} 
No & 161 & 259 & 254 & 208 & 882 \\
& $18.3 \%$ & $29.4 \%$ & $28.8 \%$ & $23.6 \%$ & \\
& $88.5 \%$ & $89.0 \%$ & $87.9 \%$ & $92.0 \%$ & \\
\hline \multirow{2}{*}{ Total } & 182 & 291 & 289 & 226 &
\end{tabular}

$\chi^{2}(3)=2.526, p>0.05$

\section{CONCLUSION}

This paper looks at the profile of graduates who perceived ethics courses taken while they were studying at the university as useful, imperative and applicable to their work environment. Basieally, graduates were asked to rate the usefulness of these ethics courses to their present career. This information is particulanly important to our university because all students are required to take the Introduction to Ethics course, and we want this course to have an impact on their work life later on in life. In general, we can conclude to a point, these ethics courses have significance to their work life, at least between eight to $28 \%$ of our graduates.

However, upon closer examination, it was found that some graduates stated greater appreciation and recognize the usefulness of the Introduction to Ethics course to their present career as compared to other graduates. Specifically, it was noted that only one demographic variable was significant, that is more female graduates declared greater appreciation towards the introductory ethics course. The Malay and Chinese graduates, those with urban environmental influence, graduates with high academic attainment and are employed in the private sector and graduates with higher income tend to view the introductory course as less beneficial to their career if compared to graduates from other background.

For the Management Ethics course, a slightly different graduate profile was observed. Those who ranked this course among the top five are from other races and the Malays, those who come from East Malaysia (the states of Sabah and Sarawak), those with better academic attainments, which serve in the government sector and with slightly high-income bracket. As for the necessity of ethics courses, only $10 \%$ affirmed its importance and they are the Malays, who are from the rural area, those with lower academic achievements, and those who serve with the statutory body.

The main difference between the Introduction to Ethics course and the Management Ethics course may be attributed to the different approach and manner in which the courses were handled. The Management Ethics course employed the case study approach, meaning that the stwdents are hrought closer to the actual situation compared to a classroom lecture style, which tend to be theoretical, abstract and metaphoric. This gap may create a lackadaisical attitude and detachment from the subject matter, thus having a lesser impact 
$\begin{array}{lllll}89.8 \% & 90.3 \% & 81.4 \% & 78.9 \% & 91.8 \%\end{array}$

$\begin{array}{lllllll}\text { Total } & 958 & 31 & 43 & 19 & 49 & 1,100\end{array}$

$\overline{\chi^{2}(4)=5.553, p>0.05}$

Finally, there seems to be no significant association as to the importance of these ethics courses with income level of our graduates. We found that the mid high income group (>RM2,000.00) gave less favorable response to this item (Table 24). In summary, the profile of graduates who perceive that the ethics courses as useful when compared to other courses taken while they were students at UUM is as follows: They are of the Malay ethnic group, who were brought up and being influenced more by the rural environment and obtained low academic achievements.

\section{Table 23}

The Necessity of Ethics Courses Compared to other Courses according to Present Employment Sector

\begin{tabular}{ccccc}
\multicolumn{3}{c}{ Employment sector } & & Total \\
Government & Statutory & Private & Own & \\
Service & Body & & Business &
\end{tabular}

$\begin{array}{lccccc}\text { Yes } & 27 & 5 & 75 & 0 & 107 \\ & 25.2 \% & 4.7 \% & 70.1 \% & & \\ & 13.7 \% & 16.1 \% & 9.5 \% & & \\ \text { No } & & & & & \\ & 170 & 26 & 712 & 2 & 910 \\ & 18.7 \% & 2.9 \% & 78.2 \% & 0.3 \% & \\ & 86.3 \% & 83.9 \% & 90.5 \% & 100.0 \% & \\ \text { Total } & & & & & 1,017 \\ & & 31 & 787 & 2 & \end{array}$

Table 24

The Necessity of Ethics Courses Compared to other Courses according to Income Group

\begin{tabular}{ccccc}
\multicolumn{5}{c}{ Income group } \\
Less & RM1,000- & RM1,501- & More than & Total \\
RM1,000.00 & RM1,500 & RM2,000 & RM2,000 & \\
& & & & \\
21 & 32 & 35 & 18 & 106 \\
$19.8 \%$ & $30.2 \%$ & $33.0 \%$ & $17.0 \%$ & \\
$11.5 \%$ & $11.0 \%$ & $12.1 \%$ & $8.0 \%$ &
\end{tabular}




\section{REFERENCES}

Afzal Iqbal, 1992. The Diplomacy of Prophet Muhammad pbuh. (Trans.) Azaman Muhammad. Kuala Lumpur: Pustaka Salam.

Bloom, M. \& Fischer, J. 1992. Evaluating Practice: Guidelines for the Accountable Profession. Englewood Cliffs, New Jersey: Prentice Hall.

Borrie, S. J. 1980. Commercial Law. London: Butterworth.

Cherrington, D. J. 1998. Work Ethics: Working Values and Values That Work. New York: Amacom.

Crooks, R. H. 1995. An Introduction to Christian Ethics. Englewood Cliffs, New Jersey: Prentice Hall.

DeCallieres, F. C. 1994. The Art of Diplomacy: Baltimore, MD: University of America Press.

Denise, T. C. Peterfreund, S. P \& White, N. P. 1999. Great Traditions in Ethics. ( $9^{\text {th }}$ Edition). Englewood Cliffs, New Jersey: Prentice Hall.

Kerner, G. 1966. The Revolution in Ethical Theory. New York: Oxford.

Joshua, H. 1988. Virtues and Values: An Introduction to Ethics. Englewood Cliffs, New Jersey: Prentice Hall.

Mahoney, S. 1990. Teaching Business Ethics in the UK, Europe and the USA: A Comparative Study. London: Athlone Press.

Matthews, M. C. 1988. Strategies Intervention in Organization Involving Ethical Dilemmas. Englewood Cliffs, New Jersey: Prentice Hall.

Mahmood, N. M. \& Sabitha Marican. 1995. Hubungan Di Antara Etika dan Nilai Kerja dengan Prestasi Kerja (The relationship between work ethic and work value with job performance). Malaysian Journal of Psychology (PSIMA), 9(a), 79-92.

Mahmood, N. M., Sabitha, Marican \& Noran Fauziah Yaakub. 2001. Teaching of Ethics: The UUM Experience. Paper presented at the ASAIHL SeminarRegional Cooperation in Good Governance, Ethics and Justice, 17-18 May, Brisbane, Australia.

Mahmood, N. M. \& Sabitha Marican. 2001. Nilai, Etika Di Tempat Kerja dan Tingkah Laku Penggerak Etika. Implikasi Kepada Prosedur Pengaduan di Dalam dan Luar Organisasi. Proceedings: BPR Management Ethics Convention, Kuala Lumpur: BPR.

Mahmood, N. M. \& Sabitha Marican. 2002. Pembentukan Tingkah Laku Positif Ke Arah Kecemerlangan Organisasi. Paper presented at the $4^{\text {th }}$ National Seminar on Counseling: Counseling as a Platform for Organizational Excellence, 1-3 November, Langkawi, Malaysia.

Mohd Salleh D., Mahmood, N. M., Mustafa, M. H., Zolkapli, H. Abdul Razak, S., Abdul Malek, A. K., \& Abdul Razak, C. 2001. UUM Tracer Study: 1995-1999.

Oemar Hamdan, Mahmood, N. M., Sabitha, M. \& Muhamad Dzahir Kasa. 2004. Work Values and Work Climate Among Muslim Workers. Proceedings of the Internal Symposium on Human Resource Strategies for Sustainable 
on their real life situation due to low retention of the subject matter. However, another pertinent issue is that there are clear differences between the ways the Chinese graduates perceived the importance of ethics courses as compared to the other ethnic groups. Upon closer inspection, the Chinese graduates tend to appreciate the technical courses that lend them direct skills for the job market, such as knowledge in IT, accounting, finance, banking, economics and business, while the other ethnic groups tend to have more appreciation for non-technical subject matters such as ethics, communications, sociology, arts and languages.

In general, we also see that these non-technical courses were less appreciated by the high achievers, and that this group goes for the technical and high market-demand courses as mentioned above. This is quite typical of students with high CGPA scores. We also observe that graduates who were brought up in the rural environment have more appreciation for the ethics courses. In Malaysia, the general observation is that community relationship in the rural area is closer, more adherence to religious practices and more parental and communal involvement in the upbringing of the child. Thus, greater emphasis is given to good moral practices and values.

Another observation is the difference in perception between those who serve in the private versus the public sector. UUM graduates serving in the public sector (including statutory bodies) tend to place greater emphasis on ethics than those who serve in the private sector, though the number are quite small. This difference is probably due to the fact that there has been a lot of emphasis on ethical work behavior in the government, since the early 1990's with the 12 pillars of ethical behavior campaign. On the other hand, the private sector usually operates according to their on their own guidelines, some may be stringent, some otherwise.

In conclusion, the ethics course in UUM may have brought impact to some eight to $28 \%$ of our graduates. This number can be considered small since ethics was considered to be one of the cornerstones of UUM's management program. It seems that students put more value on courses which support their career requirements, such as communication skills, English, IT, economics, quantitative methods, accounting and finance as opposed to social science courses such as ethics. How can ethics course be made more interesting so that students will naturally have an interest to learn and later apply it at their workplace? Thus, one implication to this observation is that UUM must formulate new approach to the teaching of ethics. Case studies methods, for example, were proven to be more effective then classroom-lecture style, and this could be one approach that can be used to increase student's interest in learning ethics and later applying it to their work place. All in all, we are all hoping for a more ethical work environment in the country. 
September.

Sabitha, M. \& Mahmood, N. M. 2005. Hubungan Di Antara Etika dan Nilai

Kerja dengan Prestasi Kerja. In. Sabitha Marican (Ed.). Membentuk Suasana Kerja Positif: Aspek Manusia dan Persekitaran Sosial. Kuala Lumpur: Utusan Publication and Distributors.

Saral, J. 1995. Aspects of Hindu Morality. Delhi: Motilal Banarsidass.

Stroh, G. 1979. American Ethical Thoughts. Chicago: Nelson-Hall.

Thiroux, J. 1995. Ethics: Theory and Practice. ( $5^{\text {th }}$ Edition). Englewood Cliffs, New Jersey: Prentice Hall.

UUM Academic Calendar. 2000. Sintok, Kedah: Academic Affairs Department, UUM.

White, T. I. 1992. Right and Wrong: A Brief Guide to Understanding Ethics. Singapore: Prentice Hall International Edition.

Mahmood N. Mohamed, Ph.D

Profesor

Fakulti Pembangunan Sosial dan Manusia

06010 Universiti Utara Malaysia

Sintok, Kedah Darul Aman, Malaysia

Sabitha Marican, $P h . D$

Profesor Madya

Fakulti Pengurusan Awam dan Undang-Undang

06010 Universiti Utara Malaysia

Sintok, Kedah Darul Aman, Malaysia 
Competitiveness, Surabaya, Indonesia.

Percesepe, G. 1995. Introduction to Ethics: Personal and Social Responsibilities in a Diverse World. Englewood Cliffs, New Jersey: Prentice Hall.

Quassem, A. 1975. The Ethics of Al Ghazali: A Composite Ethics in Islam. Kuala Lumpur: Pustaka Salam.

Sabitha, M. 1999. Perception of Sexual Harassment Among Public Administrators in Malaysia. Paper presented at The $3^{\text {rd }}$ Social Psychology Conference, Taipei, Taiwan, August $15^{\text {th }}$.

Sabitha, M. 2000. Persepsi Gangguan Seksual antara Laki-laki dan Wanita di Tempat kerja (The perception of sexual harassment at workplace among men and women). Paper presented at the Southeast Asian Association for Gender Studies, Malaysia Branch (SAMA), PJ., Malaysia, 16-17 